http://nv.nltu.edu.ua https://doi.org/10.15421/40290113

\author{
С. В. Вдовенко , О. Б. Гринишин ${ }^{2}$, А. В. Вдовенко \\ ${ }^{1}$ ТОВ "Укргазпромбуд", м. Київ, Україна \\ ${ }^{2}$ Національний університет "Львівська політехніка", м. Львів, Україна \\ ${ }^{3}$ Національний університет біоресурсів і природокористування Украйни, м. Київ, Украйна
}

\title{
ХАРАКТЕРИСТИКА СТІЧНИХ ВОД ТЕХНОЛОГІЧНИХ УСТАНОВОК ПЕРВИННОГО ПЕРЕРОБЛЕННЯ НАФТИ
}

Наведено розгорнуту характеристику стічних вод, що утворюються на різних технологічних установках первинного перероблення нафти (електродегідратори, атмосферна та вакуумна трубчатки), а також оцінено відповідність якісних характеристик стоків вимогам технологічних регламентів та чинних нормативних документів, що регулюють діяльність нафтопереробних заводів. Способом проведення моніторингу та виконання натурних замірів встановлено, що концентрації забруднювальних речовин у стічних водах технологічних установок первинного перероблення нафти часто перевищують встановлені внутрішньозаводські норми та не досягають показників якості найкращих доступних технологій і рекомендацій, зазначених у чинних нормативних документах. З'ясовано, що тотожні технологічні процеси навіть у межах одного нафтопереробного заводу під час перероблення однакової сировини досить сильно відрізняються за рівнем питомого водовідведення, що свідчить про недосконалість технологічних установок та необхідність їхньої модернізації, базуючись на "найкращих практиках" у нафтопереробній промисловості. Обгрунтовано, що існуючі технологічні процеси первинного перероблення нафти мають значний потенціал щодо зменшення кількості стоків та покращення рівня їхнього очищення і повторного використання. Отримані дані дають змогу оцінити вплив джерел скиду технологічних установок на якість води, що надходить на загальнозаводські очисні споруди та розробити реальні заходи, виконання яких допоможе найбільш економічним способом привести скид стічних вод нафтопереробних заводів відповідно до вимог законодавства та загалом підвищити економічні показники і рівень екологічної безпеки у нафтопереробній галузі.

Ключові слова: промислові стічні води; екологічна безпека нафтопереробного заводу; водовідведення; атмосферна трубчатка; вакуумна трубчатка; електродегідратор.

Вступ. Серед промислових підприємств будь-якої країни світу нафтопереробний завод (НПЗ) є значним споживачем свіжої води, ефективне використання якої $\epsilon$ надзвичайно важливим завданням. Від якості та стабільності постачання води залежить безаварійне функціонування технологічних установок перероблення нафти та нафтопродуктів, об'єктів загальнозаводського господарства, а ступінь забруднення та кількість відведених стічних вод значно впливають на екологічну безпеку регіону, де розташований НПЗ (Benyahia, 2006).

На основі практики роботи різних НПЗ відомо, що об'єм водовідведення і склад забруднень у стоках першої та другої систем каналізації змінюється у доволі широких межах, про що свідчать дані табл. 1 (Bannov, 2006; Rudin et al., 2004; Pearce \& Whyte, 2005). Ці показники залежать від таких виробничих чинників: від технології виробництва, виду та обсягу продукції, що випускається, рівня технічного оснащення установок підприємства, від технічного стану обладнання установок перероблення нафти, рівня автоматизації та періодичності аналітичного контролю за виробничими процеса-

ми, рівня технічної дисципліни обслуговуючого персоналу установок, дотримання регламенту ведення технологічного процесу (Manovyan, 2001).

Табл. 1. Характеристика суміші стоків I та II систем каналізації НПЗ

\begin{tabular}{|c|c|c|}
\hline Назва & J система & ІІсистеми \\
\hline \multicolumn{3}{|c|}{ Вміст, мг/дм ${ }^{3}$} \\
\hline Нафтопродукти & $2000-9000$ & $10000-15000$ \\
\hline Солі загальні & 1500 & 50000 \\
\hline Завислі частинки & $50-250$ & 1000 \\
\hline Феноли & $5-8$ & $15-20$ \\
\hline Сульфіди & 2 & - \\
\hline СПАВ & - & $80-100$ \\
\hline Амонійний азот & 30 & $20-30$ \\
\hline \multicolumn{3}{|c|}{ Поглинання кисню, $\mathrm{M \Gamma O}_{2} /$ дм $^{3}$} \\
\hline Біологічне (БСК повн $)$ & $250-450$ & $300-500$ \\
\hline Хімічне (ХCК) & $400-550$ & $600-750$ \\
\hline $\mathrm{pH}$ & $7,8-8,6$ & $7,5-8,0$ \\
\hline \multicolumn{3}{|c|}{ Питомі об'єми виробничих стоків НПЗ різного профілю, м } \\
\hline Паливний & $0,23-0,95$ & $0,09-0,2$ \\
\hline Паливно-оливний & $0,38-1,5$ & $0,1-0,25$ \\
\hline $\begin{array}{l}\text { Паливно-оливний } 3 \text { наф- } \\
\text { тохімічним виробництвом }\end{array}$ & $2,0-3,0$ & $1,2-2,0$ \\
\hline
\end{tabular}

\section{Інформація про авторів:}

Вдовенко Сергій Вікторович, канд. техн. наук, головний інженер проектів. Email: vdovenko1@gmail.com

Гринишин Олег Богданович, д-р техн. наук, професор, кафедра хімічної технології переробки нафти та газу.

Email: ogrynyshyn@ukr.net

Вдовенко Альона Володимирівна, асистент, кафедра глобальної економіки. Email: vav08@ukr.net

Цитування за ДСтУ: Вдовенко С. В., Гринишин О. Б., Вдовенко А. В. Характеристика стічних вод технологічних установок первинного перероблення нафти. Науковий вісник НлтУ України. 2019, т. 29, № 1. С. 60-65.

Citation APA: Vdovenko, S. V., Grynyshyn, O. B., \& Vdovenko, A. V. (2019). Waste Water Characteristics of Primery oil Processing Units. Scientific Bulletin of UNFU, 29(1), 60-65. https://doi.org/10.15421/40290113 
Аналізуючи питання щодо підвищення рівня екологічної безпеки НПЗ завдяки раціональному використанню водних ресурсів, можна стверджувати, що його вирішення потребує чіткого розуміння характеру забруднення стічних вод кожного процесу перероблення нафти та нафтопродуктів, кількості відведеної води та умов щодо їхнього скиду у водоймище (АЕСОМ, 2010). Ці дані встановлюють способом проведення моніторингу та натурних замірів концентрацій забруднювальних речовин у стоках з урахуванням різних режимів роботи технологічних установок (Abrosimov, 2002). Тому вивчення характеристик виробничих стічних вод має важливе значення та $\epsilon$ основою для проектування нових або технічного переоснащення існуючих очисних каналізаційних споруд та системи каналізації НПЗ.

Мета роботи полягає у встановленні характеристик стічних вод технологічних процесів первинного перероблення нафти на основі моніторингових досліджень та прямих інструментальних вимірів концентрацій забруднювальних речовин у стічних водах досліджуваного НПЗ. Керуючись отриманими даними, потрібно встановити:

1) відповідність якості стічних вод вимогам внутрішньозаводських стандартів та нормативних документів;

2) чинники, які найістотніше впливають на кількісні та якісні показники скидів стічних вод від існуючих установок до системи каналізації;

3) коригувальні технологічні заходи для доведення показників скидів до рівня найкращих доступних технологій.

Методи дослідження. Під час дослідження використано загальнонаукові та спеціальні методи, зокрема: хімічні та інструментальні методи вимірювання забруднювальних речовин у стічних водах; метод порівняльного аналізу наукових праць вітчизняних та зарубіжних науковців.

Якісні характеристики стічних вод установок первинного перероблення нафти. Первинне перероблення нафти на будь-якому НПЗ починається на установках електрозневоднювання та знесолювання нафти (ЕЛЗУ), а потім на атмосферних (АТ) і вакуумних трубчатках (BT) (Self et al., 2000). Ці процеси пов'язані із споживанням цілої низки побічних речовин та реагентів, що виконують певні технологічні функції (Manovyan, 2001). До таких речовин належать:

1) вода, що використовують для різних потреб;

2) водяна пара, що використовують як технологічний компонент і теплоносій;

3) розчин деемульгаторів для зневоднювання нафти;

4) розчин аміаку для нейтралізації сірководню у потоках парів бензину та для запобігання корозії шлемових труб і конденсаторів;

5) розчин лугу для очищення світлих дистилятів.

Усі ці речовини є джерелами забруднення води. Водовідведення установок первинного перероблення нафти на досліджуваних НПЗ здійснюється наведеним нижче. Стоки ЕЛЗУ після електродегідраторів проходять охолодження у теплообмінних апаратах або змішуються з холодною водою і під залишковим тиском окремими напірними потоками виводяться 3 установок трубопроводами надземної прокладки до каналізаційного колектору. Рівень забруднення стічних вод не завжди відповідає внутрішньозаводським стандартам та рекомендаціям нормативних документів (табл. 2).

Табл. 2. Якісні характеристики стоків блоків електродегідраторів ЕЛЗУ-АТ

\begin{tabular}{|c|c|c|c|c|}
\hline Показник & ЕЛЗУ-АТ №1 & ЕЛЗУ-АТ №2 & ЕЛЗУ-АТ №3 & ЕЛЗУ-АТ №4 \\
\hline \multirow{3}{*}{ Температура, ${ }^{\circ} \mathrm{C}$} & $61,1-100$ & $50,2-78,4$ & $54,5-69,8$ & $28,5-50,4$ \\
\hline & $40 *$ & $40 *$ & $40 *$ & $40 *$ \\
\hline & $40 * *$ & $40 * *$ & $40 * *$ & $40 * *$ \\
\hline \multirow{3}{*}{ Водневий показник, pH } & $6,8-7,71$ & $7,56-7,79$ & $7,28-8,14$ & $7,15-8,25$ \\
\hline & $7-8,5^{*}$ & $7-8,5 *$ & $7-8,5^{*}$ & $7-8,5^{*}$ \\
\hline & $7-8,5 * *$ & $7-8,5 * *$ & $7-8,5 * *$ & $7-8,5 * *$ \\
\hline \multirow{3}{*}{ Нафтопродукти, мг/дм ${ }^{3}$} & $206-506$ & $1446-152580$ & $896-2119$ & $188-285$ \\
\hline & $500 *$ & $500 *$ & $300 *$ & $300 *$ \\
\hline & $300-350 * *$ & $300-350 * *$ & $300-350 * *$ & $300-350 * *$ \\
\hline Завислі частинки, мг/дм ${ }^{3}$ & $19,6-26,8$ & $235-589$ & $76,8-820$ & $14,5-41,4$ \\
\hline Сухий залишок, мг/дм ${ }^{3}$ & $4528-13087$ & $7672-16204$ & $7340-12670$ & $7912-14895$ \\
\hline Хлориди, мг/дм ${ }^{3}$ & $2199-6588$ & $3669-9216$ & $3761-7284$ & $3855-8765$ \\
\hline Сульфати, мг/дм ${ }^{3}$ & $1370-3578$ & $2216-4605$ & $2180-3389$ & $2541-3787$ \\
\hline Азот амонійний, мг/дм ${ }^{3}$ & $1,49-2,24$ & $0,3-6,26$ & $2,24-5,66$ & $1,55-4,15$ \\
\hline Сірководень, мг/дм ${ }^{3}$ & $0,12-0,54$ & $0,1-0,61$ & $0,32-0,61$ & $0,28-0,52$ \\
\hline Феноли, мг/дм ${ }^{3}$ & $1,0-5,1$ & $0,85-4,5$ & $4,5-5,7$ & $2,7-4,5$ \\
\hline Фосфати, мг/дм ${ }^{3}$ & $0,67-1,06$ & $0,58-0,82$ & $0,31-0,62$ & $0,52-0,72$ \\
\hline $\mathrm{БCK}_{5}, \mathrm{мг} \mathrm{O}_{2} /$ дм $^{3}$ & $240-1440$ & $240-804$ & $166-710$ & $201-615$ \\
\hline $\mathrm{XCK,} \mathrm{мг} \mathrm{O}_{2} /$ дм $^{3}$ & $1020-12870$ & $1440-17460$ & $1300-18320$ & $974-10087$ \\
\hline АСПАР, мг/дм ${ }^{3}$ & $1,16-2,6$ & $0,88-1,6$ & $1,28-2,5$ & $0,86-1,18$ \\
\hline Іони заліза $\mathrm{Fe}^{3+}$, мг/дм ${ }^{3}$ & $0,12-0,56$ & $0,29-0,51$ & $0,11-0,46$ & $0,17-0,29$ \\
\hline
\end{tabular}

Примітки: * - внутрішньозаводські норми; ** - рекомендації нормативних документів ВУТП-97, ПБ-09-563-03.

Сірчисто-лужні стоки від відповідних блоків залужування нафтопродуктів (бензин, керосин, дизельне паливо) установок АТ накопичуються у дренажних місткостях, потім їх вивозять пересувним транспортом на установку нейтралізації відпрацьованого лугу. Блоки залужування нафтопродуктів працюють періодично, бо значна кількість світлих дистилятів на сучасних НПЗ підлягають глибокому доочищенню на установках гідроочищення 3 метою отримання пального, що відповідають вимогам специфікацій Евро-5.
Стоки з відбортованих територій установок спрямовуються до підземної самопливної системи каналізації через приямки, що передбачені на цих майданчиках. На випусках із приямків встановлені колодязі з гідрозатворами. На території технологічних установок на лініях випуску промдощової каналізації передбачено місткості промислових стоків, які відіграють роль відстійників для відділення нафтопродуктів, що далі відкачуються насосом у дренажну лінію уловлених нафтопродуктів. Стоки з невідбортованих територій - атмосферні опади 
та пожежні води - спрямовуються до підземної самопливної системи каналізації.

Конденсат водяної пари від обігріву обладнання виводиться з установок для підживлення локальних блоків обігового водопостачання і частково до центральної конденсатної станції для повторного використання. Частково водяний конденсат на глухих ділянках паросупутників спрямовується до каналізаційної системи. Значні обсяги конденсату відводяться до каналізації у випадку зниження температури водяної пари у паровій мережі, щоби запобігти потраплянню конденсату до кубу ректифікаційної колони, що може спричиняти зростання тиску в середині апарату та призвести до збою технологічного процесу.

Водяна пара, що використовується на установках АТ як технологічний компонент, перетворюється на забруднений нафтопродуктами та іншими речовинами технологічний конденсат, утворюючи значний потік забруднених стоків. Технологічні конденсати з рефлюксних місткостей АТ відводяться для промивання сирої нафти до електродегідраторів відповідних технологічних установок або скидаються до загальнозаводської системи каналізації промислових стоків. Порівняльна характеристика конденсатів (табл. 3) різних установок АТ свідчить про можливість їхнього використання на блоках ЕЛЗУ у повному обсязі, що зменшить гідравлічне навантаження на очисні споруди та сприятиме зменшенню індексу токсичності стічних вод.
На установках ВТ також застосовується перегонка нафтових залишків із водяною парою, щоби збільшити відбір дистилятів із мазутів від їхнього потенціалу. У присутності водяної пари в ректифікаційних колонах знижується парціальний тиск нафтових парів i, як наслідок, зменшується їхня температура кипіння. Найлегші компоненти залишку випаровуються і в суміші 3 водяною парою піднімаються догори по колонах, де конденсуються у поверхневих конденсаторах-змішувачах кожухо-трубного типу. Для технологічних установок ВТ № 1 як холодоагент $є$ вода блоків обігового водопостачання, тому технологічний конденсат характеризується температурою $30-65{ }^{\circ} \mathrm{C} .3$ метою запобігання забруднення поверхонь теплообмінних апаратів 2-3 рази на тиждень здійснюється зворотне промивання обіговою водою теплообмінних апаратів протягом 10-15 хв. Технологічний конденсат ВТ № 2 виходить 3 температурою $10-16{ }^{\circ} \mathrm{C}$, що пов'язано з охолодженням водяних парів, газів розкладення та легких нафтопродуктів у кожухотрубчастих конденсаторах холодоагентом із температурою $6^{\circ} \mathrm{C}$. Це сприяє покращенню процесу конденсації парів та створенню більш глибокого вакууму, проте призводить до утворення водо-нафтової емульсії та погіршення процесу відділення конденсату від нафтопродукту в сепараторі. Технологічні конденсати установок ВТ характеризується незначним забрудненням нафтопродуктами, механічними домішками та солевмістом, тому відводиться безпосередньо до першої системи каналізації (див. табл. 3).

Табл. 3. Якісні характеристики технологічних конденсатів АТ та ВТ

\begin{tabular}{|c|c|c|c|c|}
\hline Показник & AT №2 & AT №3 & BT №1 & BT №2 \\
\hline Температура, ${ }^{\circ} \mathrm{C}$ & $42,1-47,5$ & $28,1-33,4$ & $55,3-65,6$ & $10-16$ \\
\hline Водневий показник, рН & $5,95-7,01$ & $4,71-6,24$ & $6,54-7,23$ & $3,49-6,4$ \\
\hline Нафтопродукти, мг/дм ${ }^{3}$ & $0,2-7,8$ & $0,1-4,9$ & $158-2603$ & $94,1-158$ \\
\hline Завислі частинки, мг/дм ${ }^{3}$ & $1,1-4,2$ & $2,1-4,5$ & $55-121$ & $54-75$ \\
\hline Сухий залишок, мг/дм ${ }^{3}$ & $81-252$ & $78-128$ & $543-1247$ & $85-140$ \\
\hline Хлориди, мг/дм ${ }^{3}$ & $44-145$ & $48-95$ & $151-652$ & $51-106$ \\
\hline Сульфати, мг/дм ${ }^{3}$ & $31-121$ & $28-75$ & $120-384$ & $44-62$ \\
\hline Азот амонійний, мг/дм ${ }^{3}$ & $0,45-0,87$ & $0,12-0,75$ & $2,7-51,6$ & $1,1-2,6$ \\
\hline Сірководень, мг/дм ${ }^{3}$ & $0,041-0,87$ & $0,77-1,84$ & $2,8-8,9$ & $0,8-1,9$ \\
\hline Феноли, мг/дм ${ }^{3}$ & $0,05-1,2$ & $0,01-0,97$ & $12,0-71,6$ & $19,2-41,4$ \\
\hline $\mathrm{БCK}_{5}$, мг $\mathrm{O}_{2} /$ дм $^{3}$ & $3-9$ & $4-12$ & $120-260$ & $150-340$ \\
\hline $\mathrm{XCK,} \mathrm{мг} \mathrm{O}_{2} /$ дм $^{3}$ & $380-480$ & $420-562$ & $700-750$ & $900-1050$ \\
\hline АСПАР, мг/дм ${ }^{3}$ & $0,0018-0,0095$ & $0,0019-0,0074$ & $0,16-0,45$ & $0,15-0,33$ \\
\hline Іони заліза $\mathrm{Fe}^{3+}$, мг/дм ${ }^{3}$ & $0,05-0,28$ & $0,15-1,62$ & $0,07-0,18$ & $0,15-0,98$ \\
\hline
\end{tabular}

Табл. 4. Якісні характеристики промстоків ЕЛЗУ-АТ та виробничих стоків ВТ

\begin{tabular}{|c|c|c|c|c|}
\hline Показник & ЕЛЗУ-АТ №1 & ЕЛЗУ-АТ №2 & ЕЛЗУ-АТ №3 & BT №1 \\
\hline \multirow{3}{*}{ Температура, ${ }^{\circ} \mathrm{C}$} & $24,6-39,5$ & $42,0-42,5$ & $61,4-65,7$ & $37-42$ \\
\hline & $40 *$ & $40 *$ & $40 *$ & $40 *$ \\
\hline & $40 * *$ & $40^{* *}$ & $40^{* * *}$ & $40^{* * *}$ \\
\hline \multirow{3}{*}{ Водневий показник, pH } & $7,66-7,70$ & $6,40-9,06$ & $6,8-8,07$ & $6,8-8,07$ \\
\hline & $7-8,5^{*}$ & $7-8,5^{*}$ & $7-8,5^{*}$ & $7-8,5^{*}$ \\
\hline & $7-8,5^{* *}$ & $7-8,5^{* *}$ & $7-8,5^{* *}$ & $7-8,5^{* *}$ \\
\hline \multirow{3}{*}{ Нафтопродукти, мг/дм³ } & $232-294$ & $214-981$ & $123-3224$ & $474-9546$ \\
\hline & $500 *$ & $1000 *$ & $300^{*}$ & $1000^{*}$ \\
\hline & $300-400 * *$ & $300-400 * *$ & $300-400 * *$ & $250-500 * *$ \\
\hline Завислі частинки, мг/дм ${ }^{3}$ & $95,2-156,0$ & $187-581$ & $45,7-196$ & $126-158$ \\
\hline Сухий залишок, мг/дм ${ }^{3}$ & $2577-2737$ & $9756-12529$ & $4384-9531$ & $14278-15016$ \\
\hline Хлориди, мг/дм ${ }^{3}$ & $861-991$ & $5268-6552$ & $2233-3641$ & $5318-6119$ \\
\hline Сульфати, мг/дм ${ }^{3}$ & $684-854$ & $2587-4671$ & $1334-3258$ & $2386-3922$ \\
\hline Азот амонійний, мг/дм ${ }^{3}$ & $1,0-2,98$ & $1,19-8,64$ & $1,94-4,47$ & $2,38-3,58$ \\
\hline Сірководень, мг/дм ${ }^{3}$ & $0,27-0,29$ & $0,44-0,58$ & $0,59-0,73$ & $0,1-0,36$ \\
\hline Феноли, мг/дм ${ }^{3}$ & $0,35-3,25$ & $5,5-7,0$ & $3,75-7,5$ & $3,75-17,0$ \\
\hline Фосфати, мг/дм ${ }^{3}$ & $0,3-0,36$ & $0,38-0,71$ & $0,31-0,62$ & $0,21-0,32$ \\
\hline $\mathrm{БCK}_{5}$, мг $\mathrm{O}_{2} /$ дм $^{3}$ & $160-164$ & $180-480$ & $120-142$ & $112-560$ \\
\hline $\mathrm{XCK,} \mathrm{мг} \mathrm{O}_{2} /$ дм $^{3}$ & $800-840$ & $1480-3657$ & $910-970$ & $1390-1930$ \\
\hline АСПАР, мг/дм ${ }^{3}$ & $0,68-1,09$ & $0,11-0,87$ & $0,68-1,22$ & $0,13-0,8$ \\
\hline Іони заліза $\mathrm{Fe}^{3+}, \mathrm{мг} /$ дм $^{3}$ & $0,14-0,72$ & $0,32-0,85$ & $0,17-0,59$ & $0,26-0,54$ \\
\hline
\end{tabular}

Примітки: * внутрішньозаводські норми; ** рекомендації нормативних документів ВУТП-97, ПБ-09-563-03. 
Для періодичного очищення змійовиків кожної із печей ВТ від коксового нашарування використовується пароповітряне випалювання, а суміш відділених уламків коксу з водяною парою із труб печі спрямовується до окремої місткості для охолодження і далі - у промислову каналізацію.

Виробничі стоки блоків ЕЛЗУ та АТ деяких установок ЕЛЗУ-АТ змішуються та відводяться у заводський каналізаційний колектор загальним потоком і класифікуються під час виконання аналітичного контролю як промислові стоки. Виробничі стоки установок ВТ утворюються у незначній кількості під час прибирання території установок, дренажу конденсату водяної пари, продувок генераторів водяної пари, від систем охолодження торцевих ущільнень насосних агрегатів та промивки конденсаторів кожухо трубного типу (табл. 4).

Оцінювання кількісних показників скидів установок первинного перероблення нафти. Кількість спожитої та відведеної технологічними установками води залежить від конкретної технології перероблення нафти та ії фракцій, від типу встановлених насосних агрегатів, типу встановленого теплообмінного обладнання для конденсації та охолодження технологічних потоків. Розрахункові норми водовідведення для обладнання наводяться у відповідних технологічних регламентах установок, проте на практиці фактичні обсяги стоків можуть бути значно вищими (табл. 5). Так, наприклад, на установках ЕЛЗУ-АТ № 1 та ЕЛЗУ-АТ №2 теплообмінне обладнання працює незадовільно, тому температура стоків на виході до каналізаційного колектору ін- коли досягає $100{ }^{\circ} \mathrm{C}$. Це призводить до інтенсивного випаровування емульгованих вуглеводів та до підвищеної загазованості системи каналізації, що є негативним пожежо-, вибухонебезпечним чинником. Для охолодження стоків застосовується їхнє змішування з чистою водою, що призводить до збільшення кількості стічних вод та, як наслідок, до перевантаження очисних споруд і підвищеної витрати реагентів на очищення стоків.

Аналіз кількісних та якісних показників стічних вод дає можливість оцінити шляхи щодо зменшення обсягів стоків та їхнього раціонального використання у межах самих установок та загалом на НПЗ. При цьому враховуємо найкращі досягнуті результати на аналогічних виробництвах у межах підприємства, а також найкращі світові практики щодо скорочення обсягів споживання води та відповідно водовідведення технологічними установками. Для раціоналізації водовідведення наведених у табл. 5 процесів можна запропонувати такі заходи:

- використовувати у повному обсязі технологічний конденсат для промивання нафти в електородегідраторах блоків ЕЛЗУ;

- відновити замкнену систему охолодження торцевих механічних ущільнень для відведення обігової води до блоків обігового водопостачання;

- здійснювати охолодження стоків ЕЛЗУ до температури $40{ }^{\circ} \mathrm{C}$ обіговою водою через теплообмінне обладнання;

- стежити за якістю обігової води та здійснювати продувку тільки у тому разі, коли якісні показники будуть наближатися до критичних показників, що регламентуються нормативними документами.

Табл. 5. Фактичні та регламентні питомі об'єми стоків установок ЕЛЗУ-АТ та ВТ

\begin{tabular}{|c|c|c|c|c|c|c|}
\hline $\begin{array}{c}\text { Назва } \\
\text { установки }\end{array}$ & $\begin{array}{c}\text { Назва апаратів, що } \\
\text { скидають воду }\end{array}$ & Напрям водовідведення & $\begin{array}{c}\text { Одиниця, до } \\
\text { якої віднесено } \\
\text { об'єм стоків }\end{array}$ & $\begin{array}{l}\text { Стоки I сис- } \\
\text { теми, }^{3}\end{array}$ & $\begin{array}{c}\text { Стоки II } \\
\text { системи, } \mathrm{M}^{3}\end{array}$ & Інше, $\mathbf{m}^{3}$ \\
\hline 1 & 2 & 3 & 4 & 5 & 6 & 7 \\
\hline \multirow{14}{*}{$\begin{array}{c}\text { ЕЛЗУ-АТ №1 } \\
(\text { АТ-2) }\end{array}$} & \multirow{2}{*}{$\begin{array}{l}\text { конденсатори та } \\
\text { холодильники } \\
\text { (обігова вода) }\end{array}$} & \multirow{2}{*}{$\begin{array}{l}\text { обігова вода повертається на БОВ та } \\
\text { після охолодження та очищення по- } \\
\text { вертається до обігової системи }\end{array}$} & \multirow{14}{*}{1 т нафти } & - & - & $0,897 *$ \\
\hline & & & & - & - & $1,600 * *$ \\
\hline & \multirow{2}{*}{$\begin{array}{l}\text { електродегідратори } \\
\text { (промивна вода) }\end{array}$} & \multirow{2}{*}{$\begin{array}{l}\text { промивна вода має високий рівень } \\
\text { солевмісту, тому направляється до } \\
\text { другої системи каналізації }\end{array}$} & & - & $0,109 *$ & - \\
\hline & & & & - & $0,0290 * *$ & - \\
\hline & \multirow{2}{*}{$\begin{array}{l}\text { рефлюксні місткості } \\
\text { (технологічний кон- } \\
\text { денсат) }\end{array}$} & \multirow{2}{*}{$\begin{array}{l}\text { технологічний конденсат має низь- } \\
\text { кий солевміст та направляється до } \\
\text { першої системи каналізації }\end{array}$} & & $0,017^{*}$ & - & - \\
\hline & & & & $0,0200 * *$ & - & - \\
\hline & \multirow{2}{*}{$\begin{array}{l}\text { місткості залужуван- } \\
\text { ня нафтопродуктів } \\
\text { (сірчисто-лужні } \\
\text { стоки) } \\
\end{array}$} & \multirow{2}{*}{$\begin{array}{l}\text { сірчисто-лужні стоки мають висо- } \\
\text { кий рівень рН і високий рівень со- } \\
\text { левмісту та за мірою накопичення } \\
\text { відводяться на утилізацію } \\
\end{array}$} & & - & - & $0,00021 *$ \\
\hline & & & & - & - & $\begin{array}{c}0,00043 * \\
*\end{array}$ \\
\hline & \multirow{2}{*}{$\begin{array}{l}\text { насосні агрегати } \\
\text { (обігова вода) }\end{array}$} & \multirow{2}{*}{$\begin{array}{l}\text { обігова вода охолоджує торцеві ме- } \\
\text { ханічні ущільнення з "розривом } \\
\text { струменя" і відводиться до першої } \\
\text { системи каналізації }\end{array}$} & & $0,051 *$ & - & - \\
\hline & & & & $0,0800 * *$ & - & - \\
\hline & \multirow{2}{*}{$\begin{array}{l}\text { парові трубопроводи } \\
\text { (конденсат водяної } \\
\text { пари) }\end{array}$} & \multirow{2}{*}{$\begin{array}{l}\text { конденсат водяної пари частково } \\
\text { дренується до першої системи кана- } \\
\text { лізації }\end{array}$} & & $0,006^{*}$ & - & - \\
\hline & & & & - & - & - \\
\hline & \multirow[t]{2}{*}{ продувки БОВ } & \multirow{2}{*}{$\begin{array}{l}\text { продувка обігової води } \\
\text { здійснюється до першої системи ка- } \\
\text { налізації }\end{array}$} & & $0,030^{*}$ & - & - \\
\hline & & & & $0,008 * *$ & - & - \\
\hline \multirow{8}{*}{$\begin{array}{c}\text { ЕЛЗУ-АТ №2 } \\
(\text { AТ-6) }\end{array}$} & \multirow{2}{*}{$\begin{array}{l}\text { конденсатори та хо- } \\
\text { лодильники } \\
\text { (обігова вода) }\end{array}$} & \multirow{2}{*}{$\begin{array}{l}\text { обігова вода повертається на БОВ та } \\
\text { після охолодження та очищення по- } \\
\text { вертається до обігової системи }\end{array}$} & \multirow[t]{8}{*}{1 т нафти } & - & - & $0,690^{*}$ \\
\hline & & & & - & - & $1,306 * *$ \\
\hline & \multirow{2}{*}{$\begin{array}{l}\text { електродегідратори } \\
\text { (промивна вода) }\end{array}$} & \multirow{2}{*}{$\begin{array}{l}\text { промивна вода має високий рівень } \\
\text { солевмісту, тому направляється до } \\
\text { другої системи каналізації }\end{array}$} & & - & $0,076^{*}$ & - \\
\hline & & & & - & $0,033 * *$ & - \\
\hline & \multirow{2}{*}{$\begin{array}{l}\text { рефлюксні місткості } \\
\text { (технологічний кон- } \\
\text { денсат) }\end{array}$} & \multirow{2}{*}{$\begin{array}{l}\text { технологічний конденсат має низь- } \\
\text { кий солевміст та направляється до } \\
\text { першої системи каналізації }\end{array}$} & & $0,014 *$ & - & - \\
\hline & & & & $0,017 * *$ & - & - \\
\hline & \multirow{2}{*}{$\begin{array}{l}\text { місткості залужуван- } \\
\text { ня нафтопродуктів } \\
\text { (сірчисто-лужні сто- } \\
\text { ки) }\end{array}$} & \multirow{2}{*}{$\begin{array}{l}\text { сірчисто-лужні стоки мають висо- } \\
\text { кий рівень рН і високий рівень со- } \\
\text { левмісту та за мірою накопичення } \\
\text { відводяться на утилізацію }\end{array}$} & & - & - & - \\
\hline & & & & - & - & $\underset{*}{0,00012 *}$ \\
\hline
\end{tabular}




\begin{tabular}{|c|c|c|c|c|c|c|}
\hline 1 & 2 & 3 & 4 & 5 & 6 & 7 \\
\hline & насосні агрегати & обігова вода охолоджує торцеві ме- & & - & - & - \\
\hline & (оогова вода) & $\begin{array}{l}\text { хан1чн1 ущ1льнення } 3 \text { "розривом } \\
\text { струменя" і відводиться до першої } \\
\text { системи каналізації }\end{array}$ & & - & - & - \\
\hline & парові трубопроводи & конденсат водяної пари частково & & $0,0004 *$ & - & - \\
\hline & $\begin{array}{l}\text { (конденсат водяної } \\
\text { пари) }\end{array}$ & $\begin{array}{l}\text { дренується до першої системи кана- } \\
\text { лізації }\end{array}$ & & - & - & - \\
\hline & продувки БОВ & продувка обігової води .. & & $0,0004^{*}$ & - & - \\
\hline & & $\begin{array}{l}\text { здійснюється до першої системи ка- } \\
\text { налізації }\end{array}$ & & $0,007 * *$ & - & - \\
\hline \multirow{10}{*}{ ВТ №2 (BT-2) } & конденсатори та & обігова вода повертається на БОВ та & \multirow{10}{*}{1 т мазуту } & - & - & $8,500^{*}$ \\
\hline & $\begin{array}{l}\text { холодильники } \\
\text { (обігова вода) }\end{array}$ & $\begin{array}{l}\text { після охолодження та очищення по- } \\
\text { вертається до обігової системи }\end{array}$ & & - & - & $9,524 * *$ \\
\hline & рефлюксні місткості & технологічний конденсат має низь- & & $0,065^{*}$ & & \\
\hline & $\begin{array}{l}\text { (технологічний кон- } \\
\text { денсат) }\end{array}$ & $\begin{array}{l}\text { кий солевміст та направляється до } \\
\text { першої системи каналізації }\end{array}$ & & $0,068 * *$ & & \\
\hline & насосні агрегати & обігова вода охолоджує торцеві ме- & & $0,018^{*}$ & - & - \\
\hline & (обігова вода) & $\begin{array}{l}\text { ханічні ущільнення з "розривом } \\
\text { струменя" і відводиться до першої } \\
\text { системи каналізації }\end{array}$ & & - & - & - \\
\hline & парові трубопроводи & конденсат водяної пари частково & & $0,002 *$ & - & - \\
\hline & $\begin{array}{l}\text { (конденсат водяної } \\
\text { пари) }\end{array}$ & $\begin{array}{l}\text { дренується до першої системи кана- } \\
\text { лізації }\end{array}$ & & - & - & - \\
\hline & продувки БОВ & продувка обігової води & & & & \\
\hline & & $\begin{array}{l}\text { здійснюється до першої системи ка- } \\
\text { налізації }\end{array}$ & & & & \\
\hline \multirow{10}{*}{ ВТ №3 (BT-3) } & конденсатори та & обігова вода повертається на БОВ та & \multirow{10}{*}{1 т мазуту } & - & - & $2,817 *$ \\
\hline & $\begin{array}{l}\text { холодильники } \\
\text { (обігова вода) }\end{array}$ & $\begin{array}{l}\text { після охолодження та очищення по- } \\
\text { вертається до обігової системи }\end{array}$ & & - & - & $\begin{array}{c}2,28000^{*} \\
*\end{array}$ \\
\hline & рефлюксні місткості & технологічний конденсат має низь- & & $0,0138^{*}$ & - & - \\
\hline & $\begin{array}{l}\text { (технологічний кон- } \\
\text { денсат) }\end{array}$ & $\begin{array}{l}\text { кий солевміст та направляється до } \\
\text { першої системи каналізації }\end{array}$ & & $0,0156 * *$ & - & - \\
\hline & насосні агрегати & обігова вода охолоджує торцеві ме- & & - & - & - \\
\hline & (обігова вода) & $\begin{array}{l}\text { ханічні ущільнення } 3 \text { "розривом } \\
\text { струменя" і відводиться до першої } \\
\text { системи каналізації }\end{array}$ & & - & - & - \\
\hline & парові трубопроводи & конденсат водяної пари частково & & - & - & - \\
\hline & $\begin{array}{l}\text { (конденсат водяної } \\
\text { пари) }\end{array}$ & $\begin{array}{l}\text { дренується до першої системи } \\
\text { каналізації }\end{array}$ & & - & - & - \\
\hline & продувки БОВ & продувка обігової води & & - & - & - \\
\hline & & $\begin{array}{l}\text { здійснюється до першої системи } \\
\text { каналізації }\end{array}$ & & - & - & - \\
\hline \multirow{14}{*}{$\begin{array}{c}\text { ЕЛЗУ-АТ №3 } \\
\text { (АТ-7) }\end{array}$} & конденсатори та & обігова вода повертається на БОВ та & \multirow{14}{*}{1 т нафти } & - & - & $0,645^{*}$ \\
\hline & $\begin{array}{l}\text { холодильники } \\
\text { (обігова вода) }\end{array}$ & \begin{tabular}{|l} 
пıсля охолодження та очищення по- \\
вертається до обігової системи
\end{tabular} & & - & - & $1,360 * *$ \\
\hline & електродегідратори & промивна вода має високий рівень & & - & $0,025^{*}$ & - \\
\hline & (промивна вода) & $\begin{array}{l}\text { солевмісту, тому направляється до } \\
\text { другої системи каналізації }\end{array}$ & & - & $0,03726 * *$ & - \\
\hline & рефлюксні місткості & технологічний конденсат має низь- & & $0,0141 *$ & - & - \\
\hline & $\begin{array}{l}\text { (технологічний кон- } \\
\text { денсат) }\end{array}$ & $\begin{array}{l}\text { кий солевміст та направляється до } \\
\text { першої системи каналізації }\end{array}$ & & $0,0160 * *$ & - & - \\
\hline & місткості залужуван- & сірчисто-лужні стоки мають висо- & & - & - & 0,00517 * \\
\hline & $\begin{array}{l}\text { ня нафтопродуктів } \\
\text { (сірчисто-лужні } \\
\text { стоки) }\end{array}$ & $\begin{array}{l}\text { кий рівень рН і високий рівень со- } \\
\text { левмісту та за мірою накопичення } \\
\text { відводяться на утилізацію }\end{array}$ & & - & - & $\underset{*}{0,01034 *}$ \\
\hline & насосні агрегати & обігова вода охолоджує торцеві ме- & & - & - & - \\
\hline & (обігова вода) & $\begin{array}{l}\text { ханічні ущільнення } 3 \text { "розривом } \\
\text { струменя" і відводиться до першої } \\
\text { системи каналізації }\end{array}$ & & - & - & - \\
\hline & парові трубопроводи & конденсат водяної пари частково & & - & - & - \\
\hline & $\begin{array}{l}\text { (конденсат водяної } \\
\text { пари) }\end{array}$ & $\begin{array}{l}\text { дренується до першої системи кана- } \\
\text { лізації }\end{array}$ & & - & - & - \\
\hline & продувки БОВ & продувка обігової води & & $0,0008^{*}$ & - & - \\
\hline & & $\begin{array}{l}\text { 3дійснюється до першої системи } \\
\text { каналізації }\end{array}$ & & $0,0068 * *$ & - & - \\
\hline
\end{tabular}

Примітки: * фактичні показники; ** показники, зазначені у технологічних регламентах установок; *** у розрахунках не враховуються дощові стоки та стоки, що можуть утворюватися під час пожежогасіння установок.

Питомі обсяги стоків установок первинного перероблення нафти після реалізації зазначених заходів наведено у табл. 6. Отже, реалізація зазначених заходів дає скорочення стоків за першою системою на $36 \%$ i другою системою на $38 \%$.

Висновки. Результати моніторингових дослідження довели, що концентрації забруднювальних речовин у

скидах стічних вод технологічних установок первинного перероблення нафти часто перевищують встановлені внутрішньозаводські норми та не досягають показників якості найкращих доступних технологій і рекомендацій, зазначених у чинних нормативних документах.

Водночас установки первинного перероблення нафти НПЗ мають значний потенціал щодо зменшення 
кількості стоків та покращення рівня їхнього очищення і повторного використання. Виявленню резервів виробництва сприяє запровадження системи екологічного моніторингу, що дає змогу своєчасно виявляти та усувати технологічні недоліки, що впливають на рівень водоспоживання та водовідведення установок, базуючись на найкращих світових практиках.

Табл. 6. Питомі обсяги стоків установок ЕЛЗУ-АТ та ВТ

\begin{tabular}{|c|c|c|c|c|}
\hline \multirow[b]{2}{*}{$\begin{array}{c}\text { Технологічна } \\
\text { установка }\end{array}$} & \multicolumn{2}{|c|}{ Поточний стан } & \multicolumn{2}{|c|}{$\begin{array}{c}\text { Після реалізації захо- } \\
\text { дів } \\
\end{array}$} \\
\hline & $\begin{array}{c}\text { питомі } \\
\text { стоки I } \\
\text { системи, } \\
\text { м }^{3}\end{array}$ & $\begin{array}{c}\text { питомі } \\
\text { стоки II } \\
\text { системи, } \\
\text { м }^{3} \\
\end{array}$ & $\begin{array}{c}\text { питомі } \\
\text { стоки I } \\
\text { системи, } \\
\mathrm{m}^{3} \\
\end{array}$ & $\begin{array}{c}\text { питомі } \\
\text { стоки II } \\
\text { системи, } \\
\text { м }^{3} \\
\end{array}$ \\
\hline ЕЛЗУ-АТ №1 & 0,1051 & 0,1090 & 0,0637 & 0,0333 \\
\hline ЕЛЗУ-АТ №2 & 0,0147 & 0,0759 & 0,0026 & 0,0237 \\
\hline ЕЛЗУ-АТ №3 & 0,0149 & 0,0246 & 0,0020 & 0,0246 \\
\hline BT №1 & 0,0840 & - & 0,0665 & - \\
\hline BT №2 & 0,0138 & - & 0,0138 & - \\
\hline Усього & 0,2326 & 0,2094 & 0,1486 & 0,0816 \\
\hline
\end{tabular}

Реалізація заходів $з$ оптимізації норм водоспоживання та водовідведення для установок первинного перероблення нафти дає змогу заощадити енергетичні ре- сурси та створює передумови для покращення екологічних та економічних показників роботи НПЗ.

\section{Перелік використаних джерел}

Abrosimov, A. A. (2002). Ecology of hydrocarbon material processing. Moscow: Khimiia, 608 p. [In Russian].

AECOM. (2010). Petroleum refining water/wastewater use and management. London: IPIECA.

Bannov, P. G. (2006). The main control methods of environmental pollution at refineries. St. Peterburg: Khimizdat, 304 p. [In Russian].

Benyahia, F. (2006). Refinery wastewater treatment: a true technological challenge. The seventh annual U.A.E. university research conference. COE-1-COE-8. https://doi.org/10.13140/RG.2.1.4642.8562

Manovian, A. K. (2001). Oil and gas primary processing. Moscow: Khimiia, 569 p. [In Russian].

Pearce, K., \& Whyte, D. (2005). Water and wastewater management in the oil refining and re-refining industry. Republic of South Africa: Water research commission.

Rudin, M. G., Somov, A. S., \& Fomin, V. E. (2004). Pocket reference book of oil-refining industry worker. Moscow: TCNIITEneftekhim. 333 p. [In Russian].

Self, F., Ekholm, E., \& Bowers, K. (2000). Refining overview - petroleum, processes and products. Texas: American institute of chemical engineers.

S. V. Vdovenko', O. B. Grynyshyn ${ }^{2}$, A. V. Vdovenko ${ }^{3}$

1 "Ukrgasprombud" Co Ltd, Kyiv, Ukraine

${ }^{2}$ Lviv Polytechnic National University, Lviv, Ukraine

${ }^{3}$ National University of Life and Environmental Sciences of Ukraine, Kyiv, Ukraine

\section{WASTE WATER CHARACTERISTICS OF PRIMERY OIL PROCESSING UNITS}

A detailed description of wastewater generated at various process units for primary oil refining (electric dehydrators, atmospheric and vacuum tubes) is given, and an assessment is made of the compliance of the quality characteristics of the effluent with the requirements of technological regulations and the current regulatory documents governing the activities of oil refineries. By monitoring and performance of field measurements, it has been established that the concentrations of pollutants in the waste waters of primary oil processing plants often exceed the established in-plant standards, and do not reach the quality indicators of the best available technologies and recommendations specified in the current regulatory documents. It was found out that the identical technological processes, even within the same oil refinery when processing the same raw materials, differ significantly in terms of specific waste water, which indicates the imperfection of technological installations and the need for their modernization, based on "best practices" in the oil refining industry. It is substantiated that the existing technological processes of primary oil refining have a significant potential for reducing the amount of waste and improving the level of their purification and reuse. The obtained data make it possible to assess the influence of sources of discharge of process units on the quality of water entering the plant's general treatment facilities and outline real measures whose implementation will allow the most economical way to bring the discharge of sewage from oil refineries into compliance with the requirements of legislation and, on the whole, improve economic indexes and the level of environmental safety in the oil refining industry.

Keywords: industrial waste water; oil refinery environmental safety; water drainage; atmospheric distillation unit; vacuum distillation unit; desalter. 